OPEN ACCESS

Edited by:

Kumelachew Yeshitela Habtemariam, Addis Ababa University, Ethiopia

Reviewed by: Tao Lin,

Institute of Urban Environment (CAS), China

Danielle Sinnett,

University of the West of England,

United Kingdom

*Correspondence:

Sarel S. Cilliers

Sarel.Cilliers@nwu.ac.za

Specialty section: This article was submitted to

Urban Greening,

a section of the journal

Frontiers in Sustainable Cities

Received: 15 June 2021

Accepted: 17 August 2021

Published: 14 September 2021

Citation:

Van Zyl B, Lategan LG, Cilliers EJ and Cilliers SS (2021) An Exploratory

Case-Study Approach to Understand Multifunctionality in Urban Green Infrastructure Planning in a South African Context. Front. Sustain. Cities 3:725539. doi: 10.3389/frsc.2021.725539

\section{An Exploratory Case-Study Approach to Understand Multifunctionality in Urban Green Infrastructure Planning in a South African Context}

\author{
Burne Van Zyl ${ }^{1}$, Louis G. Lategan ${ }^{1}$, Elizelle J. Cilliers ${ }^{1,2}$ and Sarel S. Cilliers ${ }^{1 *}$ \\ ${ }^{1}$ Unit for Environmental Sciences and Management, North West University, Potchefstroom, South Africa, ${ }^{2}$ School of Built \\ Environment, University of Technology Sydney, Sydney, NSW, Australia
}

The United Nations Sustainable Development Goals (SDGs) intend to encourage liveable urban environments by 2030 with a main focus on strategies to achieve environmental and human well-being. In the same way, the multifunctionality principle of green infrastructure planning aims to develop and protect urban green spaces to provide several ecosystem services to increase human well-being whilst protecting the environment. With this in mind, this paper seeks to gather evidence on the nexus between multifunctionality and green infrastructure planning to achieve the SDGs within a South African context. The implementation of green infrastructure to this effect depends on creating awareness of different typologies of green infrastructure elements and the ecosystem services they provide to strengthen the implementation of the green infrastructure concept in urban planning practice. Within the aim of context-specific considerations to green infrastructure planning, green infrastructure typologies possible for implementation within a South Africa urban planning practice context are considerably more limited. A qualitative research approach is employed using case studies identifying specific examples to explore South African green infrastructure typologies and their multifunctionality. Different multifunctionality concepts are recognized by urban planners in South Africa. The research findings highlighted that multifunctionality achieved through green infrastructure planning should inform urban planning practice to promote the integration of ecological considerations. The paper ultimately provides a deeper insight into the expanding field of green infrastructure research in a South African context by underlining context-based multifunctional green infrastructure typologies and accordingly emphasizes, mainstreaming the ecosystem services concept as part of urban planning practice to address the SDGs locally.

Keywords: urban green infrastructure typologies, urban planning, urban ecology, ecosystem services, multifunctionality 


\section{INTRODUCTION}

Urbanization is regarded as the 21st century's most transformative force, intensifying social, economic, and environmental demands (Watson, 2016). Mounting evidence suggests that human activity within and outside human settlements (Maes et al., 2019) is causing global environmental change, thrusting the world into a new geological epoch, the Anthropocene (Griggs et al., 2013). The pressures caused by human activities risk extensive, unexpected, and potentially irreversible changes to basic earth-system processes as planetary boundaries are pushed to the limits. These cause risks at global and local scales including climate change; terrestrial and marine biodiversity loss; interference with the nitrogen and phosphorus cycles; stratospheric ozone depletion; ocean acidification; global freshwater shortages; chemical pollution and atmospheric aerosol loading (e.g., Griggs et al., 2013; Ahmed and Puppim de Oliveira, 2017; Maes et al., 2019). Growing environmental awareness and concerns as a result of such risks birthed the notion of sustainable development (Hák et al., 2016) which has evolved through different iterations, based on the fundamental premise of a more balanced approach to economic, social and environmental development (Lategan, 2017). There is international consensus that cities will increasingly present the loci where battles for sustainable development will be waged (Klopp and Petretta, 2017).

In recognition, the United Nations (UN) has increased its focus on urban areas, from cities as platforms, to cities as vectors for change (Watson, 2016). Whereas the Millennium Development Goals (MDGs) (2000-2015), provided eight broad goals to guide more sustainable development approaches and presented an urban dimension, cities were largely neglected (Klopp and Petretta, 2017). A stronger focus on cities emerged in the 17 Sustainable Development Goals (SDGs) released by the UN in 2016 as part of the 2030 Agenda for Sustainable Development (Valencia et al., 2019). The 17 SDGs extended the MDGs, but placed a more profound emphasis on the links between the economic, social and environmental aspects of sustainability (Stafford-Smith et al., 2017). Each SDG is accompanied by several targets and indicators (Valencia et al., 2019). An independent urban goal was included as SDG 11, to "Make cities and human settlements inclusive, safe, resilient, and sustainable," supported by ten specific targets (United Nations, 2021).

Alternative greener development approaches may hold substantial promise for more sustainable urban development in fulfillment of multiple targets set under SDG 11. An area of increasing research interest is the application of naturebased solutions to complement and/or replace traditional urban development instruments in this regard. As such, green infrastructure (GI), also termed sustainable infrastructure (Chatzimentor et al., 2020), is now a major transdisciplinary research theme that transects geography, ecology and urban planning (Benton-Short et al., 2019). Despite its prevalence, the GI concept remains contested (Benedict and McMahon, 2006, p. 1; Davies et al., 2006), often being context-based and defined (Benedict and McMahon, 2006, p. 1; Wright, 2011, p. 1007).
We define GI as: "An interconnected network within an urban area, consisting of a broad range of environmental features (including all natural, semi-natural, and man-made green and blue spaces) planned, designed, and managed to conserve ecosystem functions, contributing to biodiversity conservation and providing social, economic, and health benefits to humans by delivering multiple ecosystem services" (Benedict and McMahon, 2006; Cilliers and Cilliers, 2016). The delivery of these potential benefits, as ecosystem services (ES) (see section Ecosystem Services Delivered By Green Infrastructure), is facilitated by the multifunctionality that GI can provide through its varied constituent environmental features, or elements (Hansen et al., 2019). Multifunctionality, as a core feature of GI, can serve various objectives across the urban-rural divide, administrative scales and policy sectors (Chatzimentor et al., 2020). Accordingly, support for ecosystem-based approaches is not limited to the targets set for SDG 11, but cuts across multiple spheres. For example, Maes et al. (2019) investigated the normative implications of all 169 targets for their interlinkages with urban ecosystems, finding that $54 \%$ of targets called for action in relation thereto. Despite its potential, the concept of GI multifunctionality remains elusive and poorly conceived (Hansen et al., 2019).

Research on GI has historically been localized in the Global North (developed countries), but academic publications on the subject from the Global South (developing countries) have seen a steady increase (Pauleit et al., 2021). South Africanbased research has been specifically prolific (Du Toit et al., 2018). South Africa (SA), a signatory of the SDGs, has presented several case studies on different aspects of urban GI and more sustainable planning approaches focused on major cities like Cape Town (Taylor, 2016), Durban (Roberts et al., 2012) and Johannesburg (Bobbins and Culwick, 2015) and on smaller urban areas in the Eastern Cape (e.g., Shackleton et al., 2018) and North-West provinces (e.g., Cilliers et al., 2018). This does not imply that green planning or GI is a standard approach to development or even that it is widely applied in SA. Multiple studies have commented on the lack of priority given to ecological issues in studies focussed on urban SA, as in other developing nations (Lategan and Cilliers, 2014; Cilliers, 2019, p. 455), where greenery is considered a mere luxury (Combrinck et al., 2020). Pasquini and Enqvist (2019, p. 9) relate such perceptions to a potential lack of ecological literacy. Huston (2018, p. 135) found that the limited current implementation of GI in SA can be traced to misconceptions and a lack of GI education that has led to insufficient know-how and knowledge of implementation possibilities amongst South African urban planners. Specific mention is made of a lack of knowledge on GI typologies (Cilliers and Cilliers, 2016, p. 11), as different green space categories (or GI elements), and their multifunctionality to deliver ES (Hansen et al., 2017, p. 31) that prohibit broader practical application. In a study of South African planners, Van Zyl et al. (in press) confirmed a narrow conceptualization of multifunctionality amongst planning practitioners in this regard (see section Multifunctionality as a Multifaceted Concept for an elaboration). 
This paper aims to provide evidence on the nexus between multifunctionality and GI within a South African context by delivering a preliminary framework of GI typologies and their potential ES to mainstream multifunctionality through GI in urban planning. Based on the preliminary points of departure provided in the introduction and in support of this aim, section Ecosystem Services Delivered By Green Infrastructure discusses the ES concept as an integral component of GI to highlight the multiple benefits potentially provided. In section Green Space Typologies as Green Infrastructure Elements a synopsis of GI elements as a typology inventory is presented that may deliver a variety of ES. In section Multifunctionality as a Multifaceted Concept, multifunctionality is discussed in more detail, discussing interpretations of the concept as part of GI and urban planning and its connection to sustainable development. The Introduction and sections Ecosystem Services Delivered By Green Infrastructure, Green Space Typologies as Green Infrastructure Elements, and Multifunctionality as a Multifaceted Concept inform the last sections in which a qualitative approach is followed to analyze South African case studies as examples of GI applications through various GI elements, which are then ranked from mono- to multi-functional. The last section provides South African urban planning practice with a preliminary framework comprised of examples of South African GI elements and the possible ES generated by these elements, along with the level of multifunctionality of each element to inform planning decision-making and mainstream multifunctionality through GI in urban planning. Results are further utilized to conclude on the connection between the ecological aspects and concepts of GI planning, ES, and multifunctionality.

\section{ECOSYSTEM SERVICES DELIVERED BY GREEN INFRASTRUCTURE}

Several definitions for ES have been developed in different disciplines (Cilliers et al., 2013, p. 682). An uncontroversial and universally agreed upon definition is yet to emerge (Grunewald and Bastian, 2015, p. 11). However, we synthesize ES as: "the benefits all living species (especially humans) derive, directly or indirectly, from the capacity (function) of ecosystems to provide goods and services that satisfy needs (Bolund and Hunhammar, 1999, p. 297; De Groot et al., 2010, p. 260). ES have been classified according to four categories, namely provisioning, regulating, cultural, and habitat/supporting services (TEEB, 2010; La Notte et al., 2017, p. 392).

Provisioning ES refer to the capability of natural (e.g., rivers, biomes) or semi-natural (e.g., community gardens) green spaces to contribute physical products, materials or goods consumed directly by humans (Hein et al., 2006, p. 62; Haines-Young and Potschin, 2010, p. 111; Grunewald et al., 2018, p. 13). These include food, fresh water, energy, raw materials, and medicinal plants (Hein et al., 2006, p. 62; TEEB, 2010, p. 3; Shackleton et al., 2021, p. 206). Research suggests that residents in cities of the Global South rely more on locally sourced provisioning ES than those residing in the global North, thus necessitating a more secure local supply of these ES, inter alia by providing sufficient and equitable distribution of urban GI (Shackleton et al., 2021, p. 217-219). Regulating ES include the services provided by ecosystem functions (Andersson et al., 2016, p. 446) like regulating the climate, the removal of pollutants by air and water filtration, seed dispersal and pollination, water storage, filtration, and drainage, protection from disasters such as landslides and storms or providing pest and human disease regulation (TEEB, 2010, p. 3; Colding, 2011, p. 229; GómezBaggethun and Barton, 2013, p. 178). Seeing that regulating services mostly indirectly benefit humans, these services are often less obvious to the general public (Langemeyer, 2015, p. 45). Most of the research on urban regulating ES emanates from the Global North, leading Escobedo (2021) to caution against policy formation based on principles that neglect the local contexts of the Global South's unique socio-economic conditions. Cultural ES are classified as the non-material benefits humans obtain from ecosystems that meet cultural or spiritual needs (HainesYoung and Potschin, 2010, p. 111) obtained when visiting a green space, living in a green environment or simply having access to views of green areas (Hein et al., 2006; Sharmin, 2020). The demand for cultural ES is not homogeneous as it is intrinsically linked to socio-economic profiles, needs, experiences, values and behavior (Hein et al., 2006; Wilkerson et al., 2018, p. 103; Charoenkit and Piyathamrongchai, 2019, p. 1). Examples of cultural ES include cognitive development, recreation, aesthetic experiences, spiritual enrichment and tourism opportunities, providing support to knowledge systems, accommodating social group gatherings and sense of community (Gómez-Baggethun and Barton, 2013, p. 239; Molla, 2015, p. 37). Dobbs et al., 2021, p. 258) emphasize a lack of research on cultural ES in cities of the Global South that present differences in terms of the "proportion of indigenous communities, urbanization dynamics, and environmental inequities" that require "context-specific information, instruments, or guidelines" to guide planning decisions. According to Haines-Young and Potschin (2010, p. 111) habitat services (or supporting services) do not directly benefit humans (Liquete et al., 2016, p. 250), but are necessary to facilitate the fulfillment of all other ES. Examples include the provision of natural habitats (De Groot et al., 2002, p. 396) that accommodate genetic diversity (TEEB, 2010, p. 3). Accordingly, ES are provided by the ecosystems accommodated in certain green and blue land uses that constitute important elements of GI as interconnected nodes and links (Burton and Rogerson, 2017). The following section explores the concept of green spaces as GI elements and the typologies devised in the literature.

\section{GREEN SPACE TYPOLOGIES AS GREEN INFRASTRUCTURE ELEMENTS}

Whilst an abundance of studies have defined GI, there are significantly fewer examples that have provided classifications of GI elements (Koc et al., 2017, p. 15). In terms of definitions and scope, green space may be used interchangeably with terms such as green environments, urban green spaces or open spaces to include multiple types of spaces as GI elements. For example, natural green spaces that serve as green reservations such as 
national wildlife parks and sanctuaries. Definitions often include formal or "developed" public spaces that include "hard surface" civic spaces like squares, playgrounds, public plazas, and paved areas (Dunnett et al., 2002, p. 8) with elements of soft vegetation cover (Schäffler and Swilling, 2013, p. 247; Papageorgiou and Gemenetzi, 2018, p. 86). Anthropogenically developed green areas may also be included as constituents of other urban land uses (Shackleton et al., 2018, p. 273), including parks, golf courses, botanical gardens, street trees, school grounds, and sports fields (McConnachie and Shackleton, 2010, p. 250; Schäffler and Swilling, 2013, p. 247) often primarily developed for their recreational characteristics and secondarily for their positive environmental contributions (Grunewald et al., 2018, p. 26). Several additional examples have been recognized. These include informal or undeveloped spaces, often as the remnants of existing pristine natural areas (Planchuelo et al., 2020, p. 1) or fragmented patches of natural habitats; and community and domestic gardens (Cameron et al., 2012, p. 129; Cilliers et al., 2018), in recognition of their significant contributions to urban greenery and ES (Shackleton et al., 2018). GI also includes all areas used for urban agricultural practices such as the cultivation of plants for food and the production of livestock (Drescher et al., 2021, Steenkamp et al., 2021); as well as other gray-green elements that combine vegetation with engineered technical structures or gray infrastructure (Pauleit et al., 2011, p. 272) such as green roofs, green walls; rain gardens, bioswales, or constructed wetlands (Mell, 2013, p. 153; Hansen et al., 2017, p. 9). It must be noted that several of these typologies may overlap depending on the design and use of a space and that certain elements may provide fewer or more ES.

No universal typology for green space exists as no single typology could account for diverging natural conditions (geomorphological, climatic, and biological), historical backgrounds, and social demands linked to different contexts (Cvejić et al., 2015, p. 9, p. 10; Koc et al., 2017, p. 32). Several attempts have been made to further refine green space typologies internationally and in SA based on the definitions and scope discussed. Prominent examples base classifications on scale (The Scottish Government, 2011; Cvejić et al., 2015); function (Dunnett et al., 2002; Benedict and McMahon, 2006; Davies et al., 2006; Stiles, 2009; Council for Scientific Industrial Research (CSIR), 2019); land cover (Mell, 2010; Schäffler et al., 2013); location and form (City of Tshwane., 2005; Cvejić et al., 2015); GI components (Koc et al., 2017); and as either formal or informal (Rupprecht and Byrne, 2014). Whilst discussing these individual approaches falls beyond the limits of this paper, Table 1 draws on these sources to provide a broad overview of main typologies as a preliminary inventory of GI elements (first three columns). The terms GI elements and green spaces or open spaces are used interchangeably in the table depending on use in the literature consulted.

A review of the typologies captured in the first three columns of Table 1 underlines the multifaceted nature of green spaces in urban areas and alludes to the potential for these elements to accommodate multi-functional uses to fulfill economic, social, and environmental needs. Section Multifunctionality as a Multifaceted Concept discusses multifunctionality as a concept in this regard and focusses on interpretations of the concept as part of GI and urban planning and highlights links to sustainable development.

\section{MULTIFUNCTIONALITY AS A MULTIFACETED CONCEPT}

Multifunctionality has been methodically and theoretically developed as a constituent of multiple concepts and within multiple disciplines (Van Zyl et al., in press). The principle constitutes a key feature of GI through which it references the integration or combination of different functions within a GI element that enhances the delivery of multiple economic, social, and environmental benefits (Pauleit et al., 2011; Lennon et al., 2016; Hansen et al., 2017), or ES (Hansen et al., 2019, p. 100). In urban planning, four dimensions have come to define the concept. These are (1) multifunctionality through space based on horizontal or vertical interconnection of different functions within a space (spatial coverage); (2) multifunctionality through usage to provide several activities and functions for humans and other living beings to deliver on various needs; (3) multifunctionality through the ability to provide different functions at different times; and (4) multifunctionality based on the variety of services provided by the space in service of economic, social, and environmental requirements (Živković et al., 2019, p. 206). Obvious synergies between interpretations of multifunctionality as part of GI and within the field of urban planning are thus obvious, highlighted by contributions to more sustainable development trajectories in which urban areas interact as social-ecological systems (Hansen and Pauleit, 2014, p. 525). Table 2 is a summary of the benefits of multifunctionality in relation to the three aspects of sustainability to further underscore these synergies and the inclusion of multifunctionality as a core development consideration.

Whilst multifunctionality has been defined in urban planning according to the four dimensions provided above and recognized for its contributions to sustainability (Wei, 2017, p. 4), as encapsulated in Table 2, the principle is often overlooked by urban planners (Hansen et al., 2017, p. 43; Di Marino et al., 2019 , p. 644;) or applied to a limited extent in the combination of several socio-economic, but not necessarily environmental, functions in the same area (Rodenburg and Nijkamp, 2004, p. 274; Di Marino et al., 2019, p. 644). Van Zyl et al. (in press) conducted a quantitative investigation of South African planners based on a digital survey of their conceptualization of multifunctionality in the practice of planning. Respondents could select a definition for multifunctionality based on three interpretations. Firstly, multifunctionality as an urban land use concept, referring to the spatial arrangement and concentration of mono-functional elements in the landscape. Secondly, multifunctionality, as the combination of several land uses to provide more than one activity or socio-economic function in the same space within a landscape. Thirdly, multifunctionality as a GI 
TABLE 1 | A Gl typology inventory and selected case studies with examples of specific Gl elements.

\begin{tabular}{|c|c|c|c|c|}
\hline & & GI element & Case-study & Sources \\
\hline \multirow[t]{4}{*}{$\begin{array}{l}\text { Gray-green } \\
\text { designed } \\
\text { elements }\end{array}$} & Green roof & $\begin{array}{l}\text { A vegetated landscape installed on a roof } \\
\text { surface using soil and plants in place of } \\
\text { traditional roof material }\end{array}$ & $\begin{array}{l}\text { eThekwini Municipality Green } \\
\text { Roof Pilot Project; The Priority } \\
\text { Zone rooftop garden (Durban, } \\
\text { KwaZulu-Natal) }\end{array}$ & $\begin{array}{l}\text { (eThekwini Municipality., } \\
\text { 2011, p. 11; Priority Zone } \\
\text { Durban, 2013; Pillay, 2017) }\end{array}$ \\
\hline & Green wall & $\begin{array}{l}\text { A vertical vegetated surface (e.g., facades, } \\
\text { walls, blind walls, and partition walls) }\end{array}$ & $\begin{array}{l}\text { The "Veld wall" (Rosebank, } \\
\text { Johannesburg, Gauteng) }\end{array}$ & $\begin{array}{c}\text { (Knoll, 2018, p. 29; Pro } \\
\text { Landscaper Africa, 2018, p. } \\
\text { 37) }\end{array}$ \\
\hline & $\begin{array}{l}\text { Sustainable urban } \\
\text { drainage systems } \\
\text { (constructed wetland) }\end{array}$ & $\begin{array}{l}\text { Man-made wetlands replicating natural } \\
\text { processes (e.g., water purification and } \\
\text { waste-water treatment) of natural wetlands. } \\
\text { Resemble natural wetlands, composed of } \\
\text { plants, substrate, and microorganisms }\end{array}$ & $\begin{array}{l}\text { Intaka Island constructed } \\
\text { wetland (Cape Town, Western } \\
\text { Cape) }\end{array}$ & $\begin{array}{l}\text { (University of Cape Town., } \\
\text { 2004; Planning Partners, } \\
\text { 2005; Wynne-Jones, 2005; } \\
\text { Mallett, 2017) }\end{array}$ \\
\hline & $\begin{array}{l}\text { Sustainable urban } \\
\text { drainage systems (rain }\end{array}$ & $\begin{array}{l}\text { Rain gardens are typically lowered landscaped } \\
\text { garden beds that collect rainwater from }\end{array}$ & $\begin{array}{l}\text { University of Pretoria rain garden } \\
\text { (Pretoria, Gauteng) (see }\end{array}$ & $\begin{array}{l}\text { (Dunstan and Sampson, } \\
\text { 2013; Steenberg, 2013) }\end{array}$ \\
\hline
\end{tabular}

\section{Urban \\ agriculture \\ Vertical Farming}

Community garden

Horticulture

Rooftop farming

Urban natural Urban forest remnants proximate hard surfaces and store the water for a period in the rain garden basin, so it slowly infiltrates back into the soil. Bioswales are engineered multilayered trenches with vegetation (water runoff conveyance systems) along streets and parking areas. In both rain gardens and bioswales pollutants are removed before the storm water infiltrates back into the ground

The practice of crop cultivation in vertical layers or the integration of crops on a vertical structure (e.g., a building)

Shared public or private land used for the cultivation of agricultural goods by a group, mainly for their own consumption

Public land used for agricultural purposes to grow products on a large scale product (fruits, vegetables, and other plants) used or sold to the public for medicinal purposes, food and aesthetic gratification

Comparable to a green roof but refers to the agricultural practice of cultivation of fruit and vegetables on a roof surface

An area of natural or planted trees in and around urban areas (urban woodlands, natural forests; plantations; individual trees along right of-way spaces, including streets, or verges, or pathways)

Existing natural remnant areas

Urban natural wetland and ponds

Urban river or stream
Existing natural remnants like natural and restored native ecosystems and other natural fragments of naturally occurring or rehabilitated indigenous vegetation cover of local biomes that could be included in urban nature reserves Waterbodies formed by means of sediment deposits on river banks with either permanently or periodically water and a variety of characteristic flora and fauna. Wetlands are found in and around cities and suburbs and are often placed under nature reserves for protection

Linear running water resources flowing in urban areas with artificial or natural banks characterized by vegetation and other sediments

\section{Supplementary Table 2}

The Priority Zone rooftop garden (Durban, KwaZulu-Natal)

Siyakhana Food Garden project (Johannesburg, Gauteng)

Philippi Horticultural Area (Cape Town, Western Cape)

The Priority Zone rooftop garden (Durban, Kwazulu-Natal)

Johannesburg urban forest (Johannesburg, Gauteng)

Rondebosch Common Urban Nature reserve (Cape Town, Western Cape)

Khayelitsha wetland (Khayelitsha, Cape Town, Western Cape)

Liesbeek urban river (Cape Town, Western Cape)
(Priority Zone Durban, 2013; Pillay, 2017)

(Bauta et al., 2011; Nicolle, 2011; Nino et al., 2020)

(Battersby-Lennard and Haysom, 2012; Dewar et al. 2013; Donn-Arnold, 2019)

(eThekwini Municipality., 2011, p. 11; Priority Zone Durban, 2013; Pillay, 2017)

(Schäffler and Swilling, 2013)

(Dyssell, 1993; The City of Cape Town, 2010)

(The City of Cape Town, 2016; African Centre for a Green Economy, 2017; Mathenjwa, 2017)

(Bhikha, 2013; Brill et al., 2017; Fisher-Jeffes et al., 2017; Muntjewerff et al., 2019; Kotzé, 2020) 
TABLE 1 | Continued

\begin{tabular}{|c|c|c|c|c|}
\hline & & Gl element & Case-study & Sources \\
\hline \multirow[t]{4}{*}{$\begin{array}{l}\text { Public green } \\
\text { space }\end{array}$} & $\begin{array}{l}\text { Urban park and } \\
\text { child-friendly space }\end{array}$ & $\begin{array}{l}\text { Typically a publically accessed green space } \\
\text { that includes features of vegetation (e.g., trees, } \\
\text { lawns, and flowerbeds) and water features, } \\
\text { walking paths, play areas, range of activities, } \\
\text { seating, picnic tables, and restrooms }\end{array}$ & $\begin{array}{l}\text { Green point urban park (Cape } \\
\text { Town, Western Cape) }\end{array}$ & $\begin{array}{l}\text { (The City of Cape Town, } \\
\text { 2016; Landman, 2019) }\end{array}$ \\
\hline & Botanical garden & $\begin{array}{l}\text { Institutions holding public space for the } \\
\text { conservation of diverse biodiversity for } \\
\text { research, education, display (ornamental) and } \\
\text { recreational activities. }\end{array}$ & $\begin{array}{l}\text { Kirstenbosch Botanical Garden } \\
\text { (Cape Town, Western Cape) }\end{array}$ & $\begin{array}{l}\text { (Willis and Morkel, 2008; } \\
\text { Titus and Spencer, 2015) }\end{array}$ \\
\hline & Green sport facilities & $\begin{array}{l}\text { Cultivated and fertilized grass turf suited for } \\
\text { sport activities (e.g., golf courses, football } \\
\text { fields, hockey fields etc.). }\end{array}$ & $\begin{array}{l}\text { Grimbeek Park Golf course and } \\
\text { Heilige Akker sport grounds } \\
\text { (Potchefstroom, North-West) }\end{array}$ & $\begin{array}{l}\text { (Cilliers and Cilliers, } 2015 \\
\text { and personal observations) }\end{array}$ \\
\hline & Health clinic garden & $\begin{array}{l}\text { Gardens cultivated around health facilities, } \\
\text { providing a green space to produce fruit, } \\
\text { vegetables and medicinal plants for patients of } \\
\text { the health facility and surrounding community. }\end{array}$ & $\begin{array}{l}\text { The Jan Kempdorp community } \\
\text { health center garden (Jan } \\
\text { Kempdorp, Northern Cape) }\end{array}$ & (Muller, 2019) \\
\hline Private & Private home gardens & $\begin{array}{l}\text { Privately owned space adjacent to domestic } \\
\text { dwellings that may accommodate a variety of } \\
\text { flora species for ornamental, food, medicinal, } \\
\text { and construction material uses }\end{array}$ & $\begin{array}{l}\text { Private home gardens in Cosmo } \\
\text { city (Johannesburg, Gauteng) }\end{array}$ & (Adegun, 2018) \\
\hline \multirow[t]{2}{*}{$\begin{array}{l}\text { Informal } \\
\text { green spaces }\end{array}$} & Riverbank greenery & $\begin{array}{l}\text { Vegetated publically accessed spaces along, } \\
\text { streams, and canals }\end{array}$ & $\begin{array}{l}\text { Oewersig riverbank green space } \\
\text { (Potchefstroom, North-West) }\end{array}$ & $\begin{array}{l}\text { (Cilliers and Cilliers, } 2015 \\
\text { and personal observations) }\end{array}$ \\
\hline & $\begin{array}{l}\text { Roadside or railway } \\
\text { verged greenery }\end{array}$ & $\begin{array}{l}\text { Intersections or strips of land bordering roads } \\
\text { and railway embankments that could be a few } \\
\text { centimeters to a few meters in size consisting } \\
\text { of vegetation, habitats, forest, or gardens }\end{array}$ & $\begin{array}{l}\text { Roadside greenery on } \\
\text { Brakfontein road (Pretoria, } \\
\text { Gauteng) }\end{array}$ & Personal observations \\
\hline
\end{tabular}

principle, referring to the capacity of a space to provide multiple ES within the same space in the landscape.

A total of $71 \%$ of respondents selected the "Multifunctionality as urban land use concept" definition, confirming findings in the literature (Rodenburg and Nijkamp, 2004, p. 274); 19\% selected the "Multifunctionality as a GI planning principle" definition; and $10 \%$ selected the definition for "Multifunctionality in an urban landscape" (Van Zyl et al., in press). The majority (71\%) of respondents reported considering GI at some point in previous projects. A lack of implementation strategies (25\%) and knowledge (17\%) on more ecologically minded approaches were cited to explain a lack of more significant and consistent integration of these approaches (Van Zyl et al., in press). As substantiated by these findings, the relationship between GI and multifunctionality to generate multiple ES is not yet widely recognized in South African planning.

In recognition of the literature reviewed, findings by Van Zyl et al. (in press) and the recommendation by Du Toit et al. (2018, p. 258) for local and context-based assessment of GI and the call of Hansen et al. (2017, p. 34) for the establishment of multifunctionality inventories to assist decisionmakers, the following section turns to South Africa as research focus to (1) investigate the ES generated by selected South African GI elements (based on Table 1); and (2) determine the multifunctionality of these GI elements as a framework to guide urban planners to promote multifunctionality through GI in planning. The methodology followed is detailed below.

\section{METHODOLOGY}

A qualitative research approach was employed using case studies to explore South African green infrastructure typologies and their multifunctionality. Case studies were identified based on criterion sampling and purposeful sampling. Criterion sampling involves selecting a case that meets a predetermined set of criteria (Omona, 2013, p. 180), informed for this research by the inventory of GI elements generated in the literature investigation (sections Ecosystem Services Delivered By Green Infrastructure, Green Space Typologies as Green Infrastructure Elements, and Multifunctionality as a Multifaceted Concept) (Table 1, first three columns). The GI elements identified in case studies were classified under six main GI element groups, namely (1) graygreen designed elements; (2) urban agriculture; (3) urban natural remnants; (4) public green space; (5) private green space; and (6) informal green space with 19 GI element examples (see Table 1). Following broad criterion sampling, potential case studies were further refined by means of purposeful sampling. Specific cases were selected that provided examples of GI elements from the local context that delivered "information-rich" evidence on the potential generation of ES in these categories. Determinations were made by consulting academic publications and gray literature as sources of textual data (documents) to inform the selection of cases (Bowen, 2009, p. 29). Table 1 (columns 4 and 5) illustrates the purposefully selected examples of South African GI elements included following the sampling procedure. 
TABLE 2 | Summary of the benefits of multifunctionality in relation to the aspects of sustainability.

\begin{tabular}{|c|c|}
\hline $\begin{array}{l}\text { Aspects of } \\
\text { sustainability }\end{array}$ & Benefits of multifunctionality \\
\hline $\begin{array}{l}\text { Environmental } \\
\text { aspects }\end{array}$ & $\begin{array}{l}\text { - Bio-physical characteristics provide amplified } \\
\text { ecological functions (e.g., protecting ecosystems, } \\
\text { representing natural habitats and life support systems } \\
\text { for humans) which are perceived as ES with social and } \\
\text { economic values } \\
\text { - Promotes the appreciation and protection of natural } \\
\text { remnants in urban areas }\end{array}$ \\
\hline Social aspects & $\begin{array}{l}\text { - Diversification of combined activities that attract } \\
\text { - Increaple to the space } \\
\text { positive usage of a space by diverse user groups } \\
\text { - Benefiting social cohesion via different levels of social } \\
\text { interaction } \\
\text { - Establishing more lively, attractive, and safe spaces } \\
\text { - Enriching identity and sense of place } \\
\text { - Contributing to human health and well-being }\end{array}$ \\
\hline Economic aspects & $\begin{array}{l}\text { - Encouraging local economic activity and growth } \\
\text { - Enhancing attractiveness to attract tourists and new } \\
\text { residents } \\
\text { - Increasing local land and property values } \\
\text { - Positive impact on the workforce, with augmented } \\
\text { productivity } \\
\text { - Delivering multiple municipal services (e.g., combined } \\
\text { water, waste, and storm water management) }\end{array}$ \\
\hline
\end{tabular}

Sources: Douglas and Ravetz (2011, p. 252); Konijnendijk et al. (2013); Schäffler et al. (2013, p. 12); Mejía et al. (2015, p. 530); Molla (2015, p. 93); Hansen et al. (2019, p. 13); Živković et al. (2019).

For the assessment of the ES generated by the selected examples of South African GI elements a "self-assessment" approach was followed. The self-assessment of qualitative data were based on two main aspects: (1) the identification of criteria for the assessment, and (2) determination of the extent to which criteria were met (Falchikov and Boud, 1989, p. 529). Based on the first aspect of the self-assessment approach, each selected case study was scrutinized and evaluated using a matrix of criteria to identify the potential ES provided (see Supplementary Table 1 as an example of the assessment of the ES generated by the University of Pretoria rain garden), again based on a review of available literature on the selected examples. The documents exploited were selected as they provided detailed descriptions or discussions of one of the selected GI element examples (e.g., Muller, 2019, on the Health Clinic gardens). Direct observations by the researchers, as a recognized data gathering instrument in qualitative research (Farthing, 2016, p. 133), were also employed where no discussions of case studies were represented in the literature, for example for the golf course, other sports facilities and some of the informal green spaces included. A summary of the "provision capacity" or the total ES generated by each case study in terms of GI elements is given in Supplementary Table 2.

For the second aspect of the "self-assessment" method"determination of the extent to which criteria were met," a matrix was used to determine the "level" of the four ES categories recognized within each GI element example by means of the ranking criteria captured in Table 3 using the summary in Supplementary Table 2 with the assessment results also in Table 3. Following the ranking procedure, a verdict on the level of multifunctionality presented was provided based on the matrix (Table 3).

\section{RESULTS AND DISCUSSION}

A comprehensive discussion of the results for each GI element and case study following the aforementioned analyses will not be provided. Instead, this section provides a broad overview of results, firstly presenting the ES identified in each case study (Supplementary Table 2), followed by findings on the multifunctionality of each GI element (Table 3). A framework of GI typologies and the ES provided by each GI element using case studies is created accordingly to inform planning decision making (Supplementary Table 2 and Table 3 ). Additional discussions follow based on the results illustrated.

The results captured in Supplementary Table 2 and Table 3 demonstrate that most GI elements generated several ES simultaneously and can thus be regarded as multi-functional. Two groups of GI elements specifically presented higher levels of multifunctionality, namely gray-green designed elements and urban natural remnants. On the whole, the majority of elements delivered medium (rooftop farming, the urban park, and child-friendly space, botanical garden, and riverbank greenery) and high (urban wetland and private home gardens) multifunctionality scores. Certain informal green spaces (except riverbank greenery), were, however, classified as "monofunctional". Summing the scores (ranking scales) of the different GI elements (Table 3) providing specific ES out of a possible score of 60 provide an indication of the general prominence of the different ES categories identified. All examples generated regulating ES (total scale score of 54), especially local climate regulation and air purification, as well as cultural ES (total scale score of 53), mostly by hosting recreational activities or contributing to aesthetic value. The majority of GI elements also generated habitat and supporting ES in support of other ES (total scale score of 50). Provisioning ES were identified the least (total scale score of 29)-potentially indicating a more specialized category and the need to include extremely specific GI elements when these ES are required, for example urban agricultural uses or gardens. Several studies from the Global South suggest that these areas and the various ES they provide need to be specifically and pro-actively included in urban planning and management (Shackleton, 2021; Steenkamp et al., 2021), as they are generally not recognized as "official land use(s) in many city plans" in the Global South (Pauleit et al., 2021). Private gardens proved to be highly multi-functional. Lower income areas in SA are often endowed with less private and public green spaces than middleand higher income areas and the equitable provision of urban GI, including planning for larger residential plots requires special consideration (McConnachie and Shackleton, 2010; Venter et al., 2020, Shackleton, 2021). 
Assessment criteria

$\begin{array}{ll}\text { 1) The ranking scale for assessing the level of ES recognized within the four ES categories: } & \text { 2) The rankings scale allocated for the multifunctionality of each GI element: }\end{array}$

\begin{tabular}{cc}
\hline RANKINGTHE LEVEL OF ES RECOGNIZED WITHIN THE & NUMBER OF ES CATEGORIES RECOGNIZED \\
FOUR CATEGORIES (Provisioning, regulating, & ASSESSMENT OF THE MULTIFUNCTIONALITY \\
\hline
\end{tabular}

One category

Two categories with a ranking of 3

Three categories with a ranking of 3

All (four) categories with a ranking of 3
Mono-functiona

Low level multifunctionality

Medium level multifunctionality

High level multifunctionality

3 Three or more of the ES recognized within a category-Strong

Assessment results

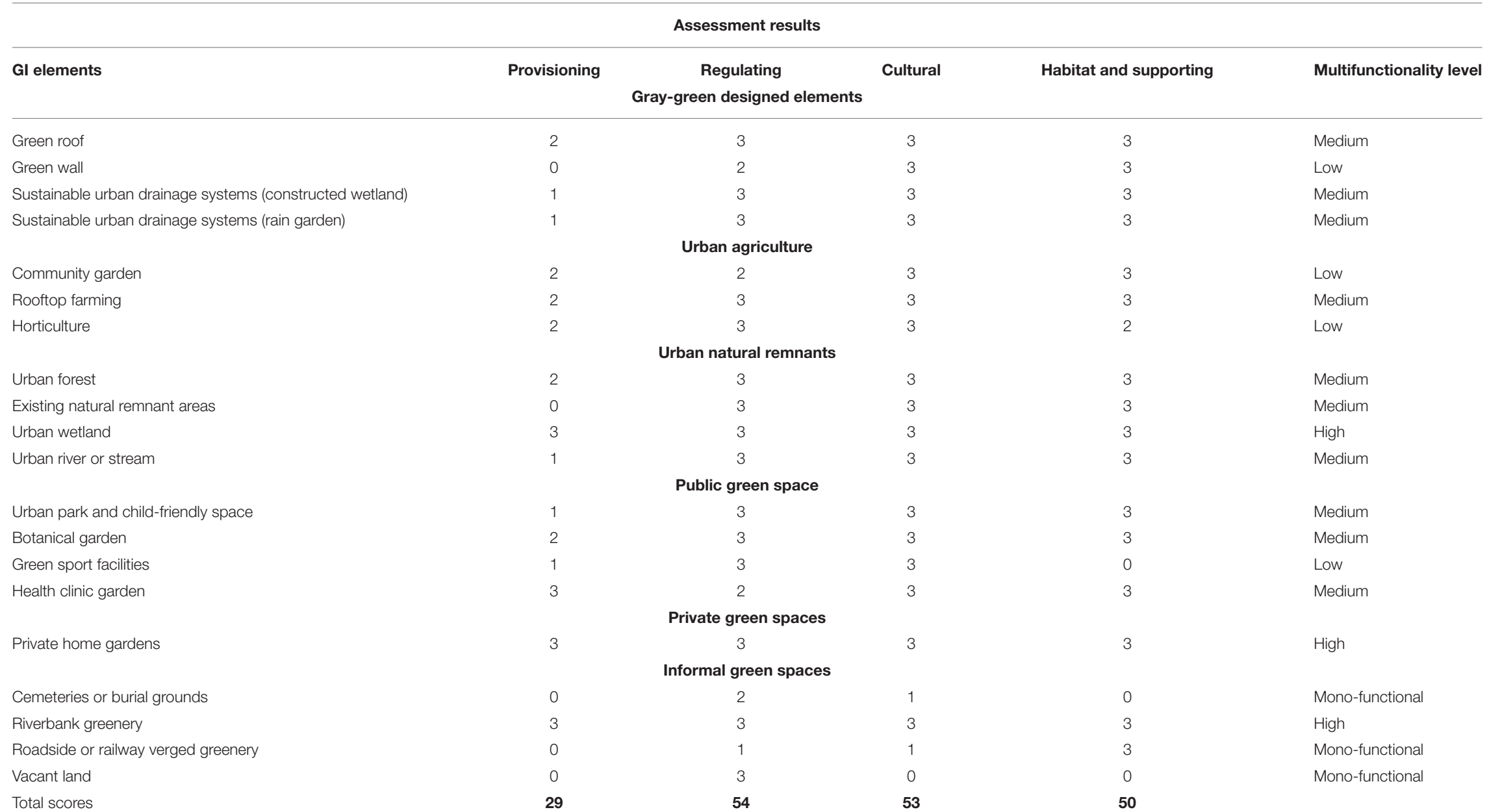


Findings indicate that whilst some individual values presented by certain GI elements may be small, ultimate value is found in the potential to provide multiple ES. For example, wetlands deliver substantial value by contributing to all ES categories, as validated by Bolund and Hunhammar (1999), De Groot et al. (2002), Gómez-Baggethun and Barton (2013), and Pfab et al. (2017, p. 10). Specific mention should also be made of the contributions delivered by natural remnants that have been discounted in the past (Muller et al., 2010, p. 3; Planchuelo et al., 2020, p. 1). The Global South is characterized by a much higher native biodiversity than the Global North and therefore urban planning in the Gobal South needs to be more vigilant to protect sensitive ecosystems and populations of species (Shackleton et al., 2021, p. 15). Many South African municipalities fail to plan for fragmented natural areas, but others have included these spaces given their location in biodiversity hot spots (Durban) (Boon et al., 2016; McLean et al., 2016) or as part of systematic conservation plans (Johannesburg and Pretoria) (Pfab et al., 2017).

Gray-green designed elements exhibited medium to high levels of multifunctionality and present great potential. South Africa has only recently started to engage with elements such as sustainable urban drainage systems (SUDS) through water sensitive urban planning and design (WSUD) solutions that incorporate constructed wetlands, rain gardens and bioswales (Fisher-Jeffes et al., 2017). Although WSUD has not yet been acknowledged in spatial planning in South Africa on a large scale, certain examples of implementation from Cape Town and Johannesburg have emerged (Carden et al., 2016, 2018, Mguni et al., 2016; Madonsela et al., 2019). Several barriers and limitations to the implementation of SUDS in cities in subSaharan Africa have been acknowledged (e.g., Mguni et al., 2016), especially the need for "social acceptance and capacity building" amongst planners (Cilliers et al., 2021) to address inequality and build a "community of practice" to implement WSUD (Carden et al., 2016).

\section{CONCLUSIONS AND RECOMMENDATIONS}

In drawing conclusions and arriving at recommendations, it is pertinent to acknowledge certain limitations of this research. The research was exploratory in nature, presenting a preliminary investigation of the potential links between multifunctionality and GI as a principle for consideration in urban planning practice. The focus on the South African context further limited the scope of the paper and in some cases there is a general lack of literature and existing empirical evidence pertaining to case studies of GI elements and ES in South Africa.

Nevertheless, the literature and case study results provided sufficient evidence of the potential in the application of various GI elements to provide multiple ES. These varied contributions may manifest as a result of the multi-functional nature of many GI elements as spaces that fulfill multiple roles to the benefit of more sustainable development outcomes. These benefits can be reconciled with multiple aspects of SDG 11 and its targets such as reducing the environmental impacts of cities by focusing on air quality and waste management (enhanced regulating ES) and by providing safe, inclusive and accessible green and public spaces (enhanced cultural ES) to name a few, but also with other SDGs and their targets (Maes et al., 2019). Whereas approaches to achieve multifunctionality through GI planning have been recognized, both the international literature and empirical evidence from South Africa (based on the explorative research captured in this paper) suggest that the approach is not widely embedded in urban planning practice. This is supported by findings presented by Van Zyl et al. (in press) on the vast majority of South African respondents not relating multifunctionality to GI planning and the lack of implementation strategies and knowledge on more ecologically minded approaches in explanation of a lack of more significant and consistent integration of GI in past projects in South Africa (Lategan and Cilliers, 2014; Cilliers and Cilliers, 2016, p. 11; Pasquini and Enqvist, 2019, p. 9) but also in the Global South (Cilliers et al., 2021, Pauleit et al., 2021).

This research addressed this knowledge and application gap by further investigating the ES (Table 3 and Supplementary Table 2) generated in case studies of specific South African GI elements (Table 1) and determining the multifunctionality of these elements as a guide (preliminary framework) (Table 3) for the broader application of multifunctionality through GI by South African planners. The investigation delivered novel contributions by presenting a comprehensive list of GI elements (Table 1), including previously neglected elements like private home gardens (Cilliers et al., 2018; Lindley et al., 2018; Shackleton et al., 2018), botanical gardens (Ward et al., 2010), green spaces used for urban agriculture (Lin et al., 2017, p. 115; Lindley et al., 2018, p. 337) and fragmented natural areas (remnants) (McLean et al., 2016) and ranking their multifunctionality.

Hölting et al. (2019) stress that optimal multifunctionality is not simply achieved by following a "the more ES the better" approach, but on the balance of numerous ES categories (provisional, cultural, regulating, and supporting services) according to context to transform existing mono-functional spaces and develop multi-functional uses. In addition, a networked approach to the achievement of multifunctionality may be sought in which multiple spaces fulfill different roles and provide different combinations of ES to address potential conflicts and synergies to the benefit of the broader urban environment. This is supported by the view of GI as an interconnected network referenced in the definition synthesized for this paper and the literature reviewed (e.g., Burton and Rogerson, 2017), inter alia by providing sufficient and equitable distribution of urban GI, especially needed in Global South cities (Shackleton, 2021, p. 217-219). For multifunctionality to be realized in the long-run, local data needs to be gathered that will convince decision-makers by presenting results of ES that contribute to quality green space, quality of life and quality urban environments (Mell, 2010, p. 58). Andersson et al. (2021) stressed the importance of local context in terms of the provision and flow of ES in cities as social-ecological-technical systems (SETS) with the aid of six case studies from the Global North. Careful 
TABLE 4 | Checklist to evaluate Gl elements.

\begin{tabular}{l}
\hline Checklist item \\
\hline Is there a synergy between multiple ecological, social, \\
and economic functions of the green space to augment \\
the ecological, social, and economic benefits of the \\
green space? \\
Are green resources combined with other types of urban \\
(gray) infrastructure (e.g., Gl elements like green roofs \\
and walls, or sustainable drainage systems)? \\
Does the green space deliver within multiple ES \\
categories? \\
Did the planning process for the green space establish \\
common ground for multiple disciplines and other \\
departments (e.g., current local governance authorities \\
and planning structures) in collaboration with \\
non-governmental stakeholders (to share input)? \\
\hline
\end{tabular}

consideration of the local context is also regarded as an important emerging issue in advancing the discipline of urban ecology and its implementation in terms of planning, management and design in the Global South, not only in terms of environmental aspects but also the divergent economic, cultural, social, and political realities facing the Global North and South (Cilliers et al., 2021, Du Toit et al., 2021).

Context-based municipal GI "registers" following the suggested preliminary framework, that capture locally implemented GI elements to identify a settlement's existing use of GI typologies, to maintain existing GI elements and recognize potential opportunities or gaps for the development of new GI elements, all in terms of the provision and flow of ES, could guide planning toward increased multifunctionality. Whilst the current study found urban wetlands and private home gardens to present the highest levels of multifunctionality, other contexts may deliver contrasting, unique results and implementation possibilities highlighted by the completion of "registers" and the execution of multifunctionality assessments. Such endeavors must be informed by stakeholder engagement processes in recognition of multifunctionality as a concept intrinsically linked to the fulfillment of multiple needs. Thus, incorporating "need-assessments" that consider how existing green spaces meet stakeholder needs and how these spaces could be improved or new spaces developed to contribute to a more sustainable environment (Boulton et al., 2018, p. 97).

Depending on the results of such processes, three management strategies for the implementation of multifunctionality through GI planning can be made (Ahern, 2007). Firstly, an offensive or opportunistic strategy relating to planning for new multi-functional green spaces through for e.g., (1) combining functions for simultaneous integration for instance developing sport fields as recreational uses that also provide regulating ES such as storm water retention or adding edible plant species to roadside verges, child-friendly spaces or green walls increasing provision ES which are especially important for the Global South (Shackleton, 2021, p. 217-219), (2) by stacking multiple functions vertically to capitalize on potential synergies through multi-layered arrangements, for example infiltration systems under buildings or parking areas and green roofs on buildings, not only increasing regulating ES but also provisioning and supporting ES, (3) differentiating and coordinating ES and functions in the same space, but shifting roles at different time intervals, for example restricting the use of hydrological systems in terms of the cultural ES they provide during high flow periods protecting their regulating and supporting ES (Rodenburg and Nijkamp, 2004, p. 274; Selman, 2009 , p. 47; Ahern, 2010, p. 147). These approaches are also reconcilable with the four dimensions of multifunctionality in urban planning mentioned in section Multifunctionality as a Multifaceted Concept. Secondly, a protective strategy that employs preventative actions to pro-actively preserve and maintain existing multi-functional GI elements, for example natural remnant areas, to avoid disturbances. Lastly, a defensive strategy that employs measures to "defend" existing multifunctional GI elements (e.g., existing natural remnants or parks) that are threatened by development pressure and constraints (Hansen et al., 2016, p. 54). The importance of protecting urban GI with high native biodiversity in Global South cities has also been emphasized, as mentioned previously (Shackleton et al., 2021, p. 15).

Finally, to achieve multifunctionality through GI planning a "checklist" (Table 4) informed by the literature reviewed and empirical results delivered, is provided. The checklist could aid urban planners within their specific environmental, economic, cultural, social and political contexts to identify existing multi-functional spaces (for the employment of the protective and defensive strategy) or to guide them toward the implementation of new multi-functional spaces (for the employment of offensive or opportunistic strategies) as part of standard planning procedure. Relating to the last checklist item on different disciplines and stakeholders, Huston's (2018) findings on a lack of GI education and limited interpretations of multifunctionality (Van Zyl et al., in press), both qualified and trainee urban planners should be educated on the nexus between multifunctionality and ES and the implementation possibilities related to various GI elements/inventories. This education should become part of planning curricula in higher education and courses for continuous professional development to empower urban planners to function with authority as part of transdisciplinary teams (Cilliers et al., 2014) and overcome disciplinary "silos" to re-scope the outlook of urban planning practice (Tan, 2017, p. 18) toward a more ecological point of departure (Ahern et al., 2014, p. 255; Tan, 2017, p. 18). This may require cross-sectoral and cross-departmental cooperation to integrate knowledge and expertise from different fields (Hansen et al., 2017, p. 66). These fields include professionals such as urban planners, engineers, landscape architects/designers and ecologists and other departments, for example local governance authorities and planning structures in collaboration with non-governmental stakeholders like public and private landowners, voluntary organizations, as well as individuals and communities toward integrated strategic GI plans that espouse multifunctionality (Selman, 2009, p. 50; Mell, 2010, p. 39; Pauleit et al., 2011, p. 257; Ahern et al., 2014; Lennon 
et al., 2016, p. 850; Wei, 2017, p. 19; Cilliers et al., 2021, p. 390). Cooperation may be challenging as Childers et al. (2015, p. 3781) argue that the only way in which a transformative integration between urban ecology and planning and design can be realized is if we can successfully train and educate a "cadre of ecologically literate urban designers and engineers; design-literate, engineering-conscious ecologists; broad-thinking and holistically inclined planners, and place-aware and activist city residents."

The GI typologies and their ES provided as the outcome of this research presents a preliminary framework from which to approach all above recommendations to mainstream multifunctionality through GI in planning. The approach holds potential to advance the sustainable development agenda, aligned to SDG 11 and others, for SA and the rest of the Global South where "weak or constrained planning and implementation of policies, plans and regulations" are regarded as major impediments (Du Toit et al., 2021), but also to address possible disparities between the Global South and Global North in GI provision (Cilliers et al., 2021; Du Toit et al., 2021; Pauleit et al., 2021). Such a framework would align to a systems perspective to urban governance, and potentially support the better management of the complex cause and effect relationships between social and ecological phenomena (Orr, 2014). Acknowledging that cities are complex social-ecologicaltechnical systems (SETS) could support Planners and Authorities to better understand multifunctionality in urban

\section{REFERENCES}

Adegun, O. B. (2018). Residents' relationship with green infrastructure in Cosmo City, Johannesburg. J. Urbanism: Int. Res Placema. Urban Sust. 11, 329-346. doi: 10.1080/17549175.2018.1470103

African Centre for a Green Economy. (2017). Exploring Landscape Green Innovations to Improve Aquatic Ecosystem Services for the Benefit of Urban and Peri-Urban Communities: A Case Study of the Khayelitsha Wetlands. South Africa: The Water Research Commission.

Ahern, J. (2007). "Green infrastructure for cities: the spatial dimension," in Cities of the Future: Towards Integrated Sustainable Water and Landscape Management, eds V. Novotny, and P. Brown (London: IWA Publishing), 267-283.

Ahern, J. (2010). "Planning and design for sustainable and resilient cities: theories, strategies, and best practices for green infrastructure," in Watercentric Sustainable Communities: Planning Retrofitting and Building the Next Urban Environment, eds. V. Novotny, J. Ahern, and P. Brown (Hoboken, NJ: Willey), 135-176.

Ahern, J., Niemelä, J., and Cilliers, S. S. (2014). The concept of ecosystem services in adaptive urban planning and design: A framework for supporting innovation. Landsc. Urban Plan. 125, 254-259. doi: 10.1016/j.landurbplan.2014.01.020

Ahmed, A., and Puppim de Oliveira, J. A. (2017). Integration of biodiversity in urban planning instruments in developing countries: the case of Kumasi Metropolitan Assembly, Ghana. J. Environ. Plan. Manage. 60, 1741-1764. doi: 10.1080/09640568.2016.1255183

Andersson, E., Barthel, S., Borgström, S., Colding, J., Elmqvist, T., Folke, C., et al. (2016). Reconnecting cities to the biosphere: stewardship of green infrastructure and urban ecosystem services. Ambio. 43, 445-453. doi: 10.1007/s13280-014-0506-y

Andersson, E., Borgström, S., Haase, D., Langemeyer, J., Mascarenhas, A., McPhearson, T., et al. (2021). A context-sensitive systems approach for green infrastructure planning and embed it in broader spatial planning approaches.

\section{DATA AVAILABILITY STATEMENT}

The original contributions presented in the study are included in the article/Supplementary Material, further inquiries can be directed to the corresponding author/s.

\section{AUTHOR CONTRIBUTIONS}

BV is the lead author, with components of this paper based on research for her Masters in Urban and Regional Planning. LL, EC, and SC were research supervisors of this research project. All authors contributed equally to the generation of the concept, writing, and revision of text for this paper and have read and agreed to the published version of the manuscript.

\section{FUNDING}

This research was funded by the National Research Foundation South Africa, grant number 116243.

\section{SUPPLEMENTARY MATERIAL}

The Supplementary Material for this article can be found online at: https://www.frontiersin.org/articles/10.3389/frsc.2021. 725539/full\#supplementary-material understanding and enabling ecosystem service realization in cities. Ecol. Soc. 26:35. doi: 10.5751/ES-12411-260235

Battersby-Lennard, J., and Haysom, G. (2012). Philippi Horticultural Area. Cape Town: AFSUN and Rooftops Canada Abri International.

Bauta, B., Kostkova, D., Parsia, S., and Restrepo, G. R. (2011). The Siyakhana Initiative for Ecological Health and Food Security. Annual Report. Available online at: http://www.siyakhana.org/ (accessed August 25, 2020).

Benedict, M. A., and McMahon, E. T. (2006). Green Infrastructure: Linking Landscapes and Communities. Washington, DC: Island Press.

Benton-Short, L., Keeley, M., and Rowland, J. (2019). Green infrastructure, green space, and sustainable urbanism: geography's important role. Urban Geogr. 40, 330-351. doi: 10.1080/02723638.2017.1360105

Bhikha, P. (2013). The Productive Landscape: Wetland Rehabilitation at the Lower Reaches of the Liesbeek River. Master's dissertation. University of Cape Town, Cape Town.

Bobbins, K., and Culwick, C. (2015). Green growth transitions through a green infrastructure approach at the local government level: case study for the Gauteng city-region. J. Public Admin. 50, 32-49. Available online at: https:// hdl.handle.net/10520/EJC175618

Bolund, P., and Hunhammar, S. (1999). Ecosystem services in urban areas. Ecol. Econ. 29, 293-301. doi: 10.1016/S0921-8009(99)00013-0

Boon, R., Cockburn, J., Douwes, E., Govender, N., Ground, L., Mclean, C., et al. (2016). Managing a threatened savanna ecosystem (KwaZulu-Natal Sandstone Sourveld) in an urban biodiversity hotspot: Durban, South Africa. Bothalia 46:a2112. doi: 10.4102/abc.v46i2.2112

Boulton, C., Dedekorkut-Howes, A., and Byrne, J. (2018). Factors shaping urban greenspace provision: a systematic review of the literature. Landsc. Urban Plan. 178, 82-101. doi: 10.1016/j.landurbplan.2018. 05.029

Bowen, G. A. (2009). Document analysis as a qualitative research method. Qual. Res. J. 9, 27-40. doi: 10.3316/QRJ0902027 
Brill, G., Anderson, P., and O'Farrell, P. (2017). Methodological and empirical considerations when assessing freshwater ecosystem service provision in a developing city context: making the best of what we have. Ecol. Indic. 76, 256-274. doi: 10.1016/j.ecolind.2017.01.006

Burton, C., and Rogerson, J. M. (2017). The making of green urban infrastructure: the Klipriviersberg Urban Biodiversity Corridor. Afr. J. Hospit. Tour. Leis. $6,1-13$.

Cameron, R. W., Blanuša, T., Taylor, J. E., Salisbury, A., Halstead, A. J., Henricot, B., et al. (2012). The domestic garden-Its contribution to urban green infrastructure. Urban For. Urban Gree. 11, 129-137. doi: 10.1016/j.ufug.2012.01.002

Carden, K., Armitage, N., Fisher-Jeffes, L., Winter, K., Mauck, B., Sanya, T., et al. (2018). Challenges and Opportunities for Implementing Water Sensitive Design in South Africa. Pretoria: WRC Project report K5/2412.

Carden, K., Ellis, D., and Armitage, N. P. (2016). "Water sensitive cities in South Africa: developing a community of practice," Proceedings of the 3rd Intn Conf on Design, Construction, Maintenance, Monitoring and Control of Urban Water Systems (UW 2016). www.witconferences.com WIT Transactions on The Built Environment. doi: 10.2495/UW160051

Charoenkit, S., and Piyathamrongchai, K. (2019). A review of urban green spaces multifunctionality assessment: a way forward for a standardized assessment and comparability. Ecol. Indic. 107:105592. doi: 10.1016/j.ecolind.2019. 105592

Chatzimentor, A., Apostolopoulou, E., and Mazaris, A. D. (2020). A review of green infrastructure research in Europe: challenges and opportunities. Landsc. Urban Plan. 198:103775. doi: 10.1016/j.landurbplan.2020.103775

Childers, D. L., Cadenasso, M. L., Grove, M. J., Marshall, V., Mcgrath, B., and Pickett, S. T. A. (2015). An ecology for cities: a transformational nexus of design and ecology to advance climate change resilience and urban sustainability. Sustainability 7, 3774-3791. doi: 10.3390/su7043774

Cilliers, E. J. (2019). Reflecting on green infrastructure and spatial planning in Africa: The complexities, perceptions, and way forward. Sustainability 11:455. doi: $10.3390 /$ sul1020455

Cilliers, J., and Cilliers, S. (2015). From green to gold: a South African example of valuing urban green spaces in some residential areas in Potchefstroom. Town Reg. Plan. 67, 1-12. Available online at: http://www.ajol.info/index.php/trp/ article/view/130508

Cilliers, J., and Cilliers, S. (2016). Planning for Green Infrastructure: Options for South African Cities. South African Cities Network.

Cilliers, S. S., Breed, C. A., Cilliers, E. J., and Lategan, L. G. (2021). "Urban ecological planning and design in the Global South," in Urban Ecology in the Global South, eds. C. M. Shackleton, S. S. Cilliers, E. Davoren, and M. J. du Toit (Cham: Springer), 365-401.

Cilliers, S. S., Cilliers, J., Lubbe, C. E., and Siebert, S. J. (2013). Ecosystem services of urban green spaces in African countries- perspectives and challenges. Urban Ecosyst. 16, 681-702. doi: 10.1007/s11252-012-0254-3

Cilliers, S. S., Du Toit, M. J., Cilliers, J., Drewes, J. E., and Retief, F. (2014). Sustainable urban landscapes: South African perspectives on transdisciplinary possibilities. Landsc. Urban Plan. 125, 260-270. doi: 10.1016/j.landurbplan.2014.02.009

Cilliers, S. S., Siebert, S. J., Du Toit, M. J., Barthel, S., Mishra, S., Cornelius, S. F., et al. (2018). Garden ecosystem services of Sub-Saharan Africa and the role of health clinic gardens as social-ecological systems. Landsc. Urban Plan. 180, 294-307. doi: 10.1016/j.landurbplan.2017.01.011

City of Tshwane. (2005). Open Space Plan. Vol. 2, Proposed Tshwane Open Space Framework. Available online at: http://www.tshwane.gov.za/sites/residents/ Services/OpenSpaceManagement/Framework/Open\%20Space\%20Framework \%20Vol\%202.pdf (accessed May 6, 2020).

Colding, J. (2011). "The role of ecosystem services in contemporary urban planning," in Urban Ecology: Patterns, Processes and Applications, eds. J. Niemelä, J. H. Breuste, T. Elmqvist, G. Guntenspergen, P. James, and N. E. McIntyre (Oxford, UK: Oxford University Press), 228-237.

Combrinck, Z., Cilliers, E. J., Lategan, L., and Cilliers, S. S. (2020). Revisiting the proximity principle with stakeholder input: investigating property values and distance to urban green space in potchefstroom. Land 9:235. doi: $10.3390 /$ land 9070235

Council for Scientific and Industrial Research (CSIR). (2019). Red Book: The Neighbourhood Planning and Design Guide. South Africa: Council for Scientific and Industrial Research, Department of Human Settlements. Available online at: https://www.ukesa.info/library/view/red-book (accessed May 8, 2020).

Cvejić, R., Eler, K., Pintar, M., Železnikar, S., Haase, D., Kabisch, N., et al. (2015). A Typology of Urban Green Spaces, Eco-System Services Provisions Services and Demands. Report D3, 1. GREEN SURGE Project (2013-2017). Available online at: https://greensurge.eu/working-packages/wp3/files/D3.1_Typology_ of_urban_green_spaces_1_.pdf/D3.1_Typology_of_urban_green_spaces_v2_. pdf (accessed May 5, 2020).

Davies, C., MacFarlane, R., McGloin, C., and Roe, M. (2006). Green Infrastructure Planning Guide. Project: Final Report. Available online at: https://www. researchgate.net/publication/265012095_GREEN_INFRASTRUCTURE_ PLANNING_GUIDE_Authors (accessed April 30, 2020).

De Groot, R. S., Alkemade, R., Braat, L., Hein, L., and Willemen, L. (2010). Challenges in integrating the concept of ecosystem services and values in landscape planning, management and decision making. Ecol. Complex. 7, 260-272. doi: 10.1016/j.ecocom.2009.10.006

De Groot, R. S., Wilson, M. A., and Boumans, R. M. (2002). A typology for the classification, description and valuation of ecosystem functions, goods and services. Ecol. Econ. 41, 393-408. doi: 10.1016/S0921-8009(02) 00089-7

Dewar, D., Cooke, J., Todeschini, F., Watson, V., and Odendaal, N. (2013, August 8). 7 reasons building on Philippi horticultural area makes no sense. Cape Times, p. 9.

Di Marino, M., Tiitu, M., Lapintie, K., Viinikka, A., and Kopperoinen, L. (2019). Integrating green infrastructure and ecosystem services in land use planning. Results from two Finnish case studies. Land Use Policy 82, 643-656. doi: 10.1016/j.landusepol.2019.01.007

Dobbs, C., Vasquez, A., Olave, P., and Olave, M. (2021). "Cultural urban ecosystem services," in Urban Ecology in the Global South, eds. C. M. Shackleton, S. S. Cilliers, E. Davoren, and M. J. du Toit (Cham: Springer), 245-264.

Donn-Arnold, N. (2019). Exploring the Links Between Urban Agriculture, Land Use and Food Security in the Philippi Horticultural Area (PHA). Master's thesis, University of the Western Cape, Cape Town.

Douglas, I., and Ravetz, J. (2011). "Urban ecology-the bigger picture," in Urban Ecology: Patterns, Processes and Applications, eds. J. Niemelä, J. H. Breuste, T. Elmqvist, G. Guntenspergen, P. James, and N. E. McIntyre (Oxford: Oxford University Press), 246-262.

Drescher, A. W., Isendahl, C. C., Cruz, M., Karg, H., and Menakanit, A. (2021). "Urban and peri-urban agriculture in the Global South," in Urban Ecology in the Global South, eds. C. M. Shackleton, S. S. Cilliers, E. Davoren, and M. J. du Toit (Cham: Springer), 293-324.

Du Toit, M. J., Cilliers, S. S., Dallimer, M., Goddard, M., Guenat, S., and Cornelius, S. F. (2018). Urban green infrastructure and ecosystem services in sub-Saharan Africa. Landsc. Urban Plan. 180, 249-261. doi: 10.1016/j.landurbplan.2018.06.001

Du Toit, M. J., Shackleton, C. M., Cilliers, S. S., and Davoren, E. (2021). "Advancing urban ecology in the Global South: emerging themes and proposed future research directions," in Urban Ecology in the Global South, eds. C. M. Shackleton, S. S. Cilliers, E. Davoren, and M. J. du Toit (Cham: Springer), 433.

Dunnett, N., Swanwick, C., and Woolley, H. (2002). Improving Urban Parks, Play Areas, and Open Space. London: Department of Transport Local Government and Regions. Available online at: https://webarchive.nationalarchives.gov.uk/ 20120920021109/http://www.communities.gov.uk/documents/communities/ pdf/131021.pdf (accessed May 5, 2020).

Dunstan, N., and Sampson, J. (2013). Landscape SA: Rainwater Harvesting At Pretoria University. Available online at: https://www.up.ac.za/media/shared/ 491/rhg-landscape-sa.zp56039.pdf (accessed August 25, 2020).

Dyssell, M. C. (1993). The Rondebosch Common: Planning for the Future. PhD dissertation, University of Cape Town, Cape Town.

Escobedo, F. J. (2021). "Understanding urban regulating ecosystem services in the Global South," in Urban Ecology in the Global South, eds. C. M. Shackleton, S. S. Cilliers, E. Davoren, and M. J. du Toit (Cham: Springer), 227-244.

eThekwini Municipality. (2011). eThekwini Municipality State of Local Innovation Report October 2011. Available online at: www.durban.gov.za (accessed August 20, 2020).

Falchikov, N., and Boud, D. (1989). Student self-assessment in higher education: a meta-analysis. Rev. Educ. Res. 59, 395-430. doi: 10.3102/003465430590 04395 
Farthing, S. (2016). Research Design in Urban Planning: A Student's Guide. London: Sage.

Fisher-Jeffes, L., Carden, K., and Armitage, N. (2017). A water sensitive urban design framework for South Africa. Town Reg. Plan. 71, 1-10. doi: 10.18820/2415-0495/trp71i1.1

Gómez-Baggethun, E., and Barton, D. N. (2013). Classifying and valuing ecosystem services for urban planning. Ecol. Econ. 86, 235-245. doi: 10.1016/j.ecolecon.2012.08.019

Griggs, D., Stafford-Smith, M., Gaffney, O., Rockström, J., Öhman, M. C., Shyamsundar, P., et al. (2013). Sustainable development goals for people and planet. Nature 495, 305-307. doi: 10.1038/495305a

Grunewald, K., and Bastian, O. (2015). "Ecosystem Services (ES): More Than Just a Vogue Term?", in Ecosystem Services-Concept, Methods and Case Studies, eds. K. Grunewald, and B. Olaf (Berlin: Springer), 1-11.

Grunewald, K., Li, J., Xie, G., and Kümper-Schlake, L. (2018). Towards Green Cities Urban Biodiversity and Ecosystem Services in China and Germany. New York, NY: Springer International Publishing.

Haines-Young, R., and Potschin, M. (2010). Proposal for a Common International Classification of Ecosystem Goods and Services (CICES) for Integrated Environmental and Economic Accounting. European Environment Agency, 30.

Hák, T., Janoušková, S., and Moldan, B. (2016). Sustainable development goals: a need for relevant indicators. Ecol. Indic. 60, 565-573. doi: 10.1016/j.ecolind.2015.08.003

Hansen, R., Olafsson, A. S., van der Jagt, A., Rall, E., and Pauleit, S. (2016). "Planning multifunctional green infrastructure in urban areas-advanced approaches based on case studies from Denmark, Germany and the UK," in Proceedings of the Fábos Conference on Landscape and Greenway Planning, Vol. 5,35 .

Hansen, R., Olafsson, A. S., van der Jagt, A. P., Rall, E., and Pauleit, S. (2019). Planning multifunctional green infrastructure for compact cities: what is the state of practice? Ecol. Indic. 96, 99-110. doi: 10.1016/j.ecolind.2017. 09.042

Hansen, R., and Pauleit, S. (2014). From multifunctionality to multiple ecosystem services? A conceptual framework for multifunctionality in green infrastructure planning for urban areas. Ambio 43, 516-529. doi: 10.1007/s13280-014-0510-2

Hansen, R., Rall, E., Chapman, E., Rolf, W., and Pauleit, S. (2017). Urban Green Infrastructure Planning: A Guide for Practitioners. Green Surge. Retrieved from: http://greensurge.eu/ working-packages/wp5/ (accessed April 26, 2021).

Hein, L., Van Koppen, K., De Groot, R. S., and Van Ierland, E. C. (2006). Spatial scales, stakeholders and the valuation of ecosystem services. Ecol. Econ. 57, 209-228. doi: 10.1016/j.ecolecon.2005.04.005

Hölting, L., Jacobs, S., Felipe-Lucia, M. R., Maes, J., Norström, A. V., Plieninger, T., et al. (2019). Measuring ecosystem multifunctionality across scales. Environ. Res. Lett. 14:124083. doi: 10.1088/1748-9326/ab5ccb

Huston, G. D. (2018). Building a Case Study for Transdisciplinary Thinking: The Inclusion of Green Infrastructure as Part of Spatial Planning Education. Master's thesis, North-West University, South Africa, Potchefstroom. Available online at: https://repository.nwu.ac.za/bitstream/handle/10394/31251/Huston_GD. pdf?isAllowed=yandsequence $=1$ (accessed April 26, 2021).

Klopp, J. M., and Petretta, D. L. (2017). The urban sustainable development goal: Indicators, complexity and the politics of measuring cities. Cities 63, 92-97. doi: 10.1016/j.cities.2016.12.019

Knoll, C. (2018). African Design Magazine: The Veld Wall Keyes Art Mile, 28-40. Available online at: https://wildflowernursery.co.za/wp-content/uploads/2018/ 06/TheVeldWall_LR.pdf (accessed August 21, 2020).

Koc, C. B., Osmond, P., and Peters, A. (2017). Towards a comprehensive green infrastructure typology: a systematic review of approaches, methods and typologies. Urban Ecosyst. 20, 15-35. doi: 10.1007/s11252-016-0578-5

Konijnendijk, C. C., Annerstedt, M., Nielsen, A. B., and Maruthaveeran, S. (2013). Benefits of Urban Parks: A Systematic Review. A Report for IPFRA. Available online at: https://www.worldurbanparks.org/images/Newsletters/ IfpraBenefitsOfUrbanParks.pdf (accessed May 10, 2020).

Kotzé, P. (2020). Liesbeek-the people's river of Cape Town. Water Wheel 19, 33-37. Available online at: https://hdl.handle.net/10520/EJC-1d51dfa29d

La Notte, A., D’Amato, D., Mäkinen, H., Paracchini, M. L., Liquete, C., Egoh, B., et al. (2017). Ecosystem services classification: a systems ecology perspective of the cascade framework. Ecol. Indic. 74, 392-402. doi: 10.1016/j.ecolind.2016.11.030
Landman, K. (2019). Evolving Public Spaces in South Africa: Towards Regenerative Space in the Post-Apartheid City. Routledge Handbook of Urban Planning in Africa. London: Routledge.

Langemeyer, J. (2015). Urban Ecosystem Services: The Value of Green Spaces in Cities. Doctoral dissertation, Stockholm Resilience Centre, Stockholm University.

Lategan, L. G. (2017). Informality and Sustainability: Reflecting on South Africa's Informal Backyard Rental Sector from a Planning Perspective. Doctoral dissertation, North-West University, Potchefstroom, South Africa. Available online at: http://hdl.handle.net/10394/25064 (accessed May 10, 2021).

Lategan, L. G., and Cilliers, E. J. (2014). The value of public green spaces and the effects of South Africa's informal backyard rental sector. WIT Trans. Ecol. Environ. 191, 427-438. doi: 10.2495/SC140361

Lennon, M., Scott, M., Collier, M., and Foley, K. (2016). Developing green infrastructure 'thinking': devising and applying an interactive group-based methodology for practitioners. J. Environ. Plan. Manag. 59, 843-865. doi: 10.1080/09640568.2015.1042152

Lin, B. B., Philpott, S. M., Jha, S., and Liere, H. (2017). "Urban agriculture as a productive green infrastructure for environmental and social well-being," in Greening Cities: Forms and Functions, eds. P. Y. Tan, and C. Y. Jim (Singapore: Springer), 155-179.

Lindley, S., Pauleit, S., Yeshitela, K., Cilliers, S., and Shackleton, C. (2018). Rethinking urban green infrastructure and ecosystem services from the perspective of sub-Saharan African cities. Landsc. Urban Plan. 180, 328-338. doi: 10.1016/j.landurbplan.2018.08.016

Liquete, C., Cid, N., Lanzanova, D., Grizzetti, B., and Reynaud, A. (2016). Perspectives on the link between ecosystem services and biodiversity: the assessment of the nursery function. Ecol. Indic. 63, 249-257. doi: 10.1016/j.ecolind.2015.11.058

Madonsela, B., Koop, S., Van Leeuwen, K., and Carden, K. (2019). Evaluation of water governance processes required to transition towards water sensitive urban design: an indicator assessment approach for the City of Cape Town. Water 11:292. doi: 10.3390/w11020292

Maes, M. J., Jones, K. E., Toledano, M. B., and Milligan, B. (2019). Mapping synergies and trade-offs between urban ecosystems and the sustainable development goals. Environ. Sci. Policy 93, 181-188. doi: 10.1016/j.envsci.2018. 12.010

Mallett, G. D. (2017). An Investigation into How Value is Created through Water Sensitive Urban Design. Master's dissertation, University of Cape Town, Cape Town.

Mathenjwa, F. (2017). Exploring the Ecological and Social Benefits of the Khayelitsha Wetlands Park. Master's dissertation, University of Cape Town, Cape Town.

McConnachie, M. M., and Shackleton, C. M. (2010). Public green space inequality in small towns in South Africa. Habitat Int. 34, 244-248. doi: 10.1016/j.habitatint.2009.09.009

McLean, C. T., Ground, L. E., Boon, R. G., Roberts, D. C., Govender, N., and McInnes, A. (2016). Durban's Systematic Conservation Assessment. Durban: eThekwini Municipality, Environmental Planning and Climate Protection Department. Available online at: http://www.durban.gov.za/City_Services/ development_planning_management/environmental_planning_climate_ protection/Publications/Documents/DurbansSystematicConservation.pdf (accessed April 26, 2019).

Mejía, C. V., Shirotova, L., and de Almeida, I. F. M. (2015). Green infrastructure and German landscape planning: a comparison of approaches. Urbani Izziv. 26, S25-S37. doi: 10.5379/urbani-izziv-en-2015-26-supplement-002

Mell, I. C. (2010). Green Infrastructure: Concepts, Perceptions and Its Use in Spatial Planning. PhD thesis. Newcastle University, Newcastle.

Mell, I. C. (2013). Can you tell a green field from a cold steel rail? Examining the "green" of Green Infrastructure development. Local Environ. 18, 152-166. doi: 10.1080/13549839.2012.719019

Mguni, P., Herslund, L., and Jensen, M. B. (2016). Sustainable urban drainage systems: examining the potential for green infrastructure-based stormwater management for Sub-Saharan cities. Nat. Hazards 82, S241-S257. doi: 10.1007/s11069-016-2309-x

Molla, M. B. (2015). The value of urban green infrastructure and its environmental response in urban ecosystem: a literature review. Int. J. Environ. Sci. 4, 89-101. Available online at: http://www.crdeepjournal.org/wp-content/uploads/2015/ 04/Vol-4-2-9-IJES.pdf 
Muller, M. (2019). Valuation of Ecosystem Services at Health Clinic Gardens in South Africa. Dissertation - MSc, North West University, Potchefstroom.

Muller, N., Werner, P., and Kelcey, J. G. (2010). Urban Biodiversity and Design. Oxford: John Wiley and Sons.

Muntjewerff, S., Tulleken, B. B., Crispijn, F., Goedhart, R., Durry, S., and Kool, J. (2019). Liesbeek River Bank A Design Proposal for the Liesbeek River bank, To Maintain, Restore and Improve the Water Quality, Water Quantity, Ecology and Amenity. Available online at: https://obs.org.za/cms/wpcontent/uploads/2019/12/Liesbeek_Project_Improved-Hydrology-Report.pdf (accessed September 8, 2020).

Nicolle, T. B. (2011). Urban Food Gardens and Community Development: A Case Study of the Siyakhana Initiative, Johannesburg. Master's thesis, University of the Witwatersrand, Johannesburg.

Nino, E. C., Lane, S., Okano, K., Rahman, I., Peng, B., Benn, H., et al. (2020). GCRO Occasional Papers. Vol. 15, Urban Agriculture in the Gauteng City-Region's Green Infrastructure Network. Gauteng City Region Observatory (GCRO).

Omona, J. (2013). Sampling in qualitative research: improving the quality of research outcomes in higher education. Makerere J. High. Educat. 4, 169-185. doi: $10.4314 /$ majohe.v4i2.4

Orr, D. (2014). Systems thinking and the future of cities. Solutions 5, 54-61. Available online at: https://www.resilience.org/stories/2014-05-30/systemsthinking-and-the-future-of-cities/

Papageorgiou, M., and Gemenetzi, G. (2018). Setting the grounds for the green infrastructure in the metropolitan areas of Athens and Thessaloniki: the role of green space. Eur. J. Environ. Sci. 8, 83-92. doi: 10.14712/23361964.2018.12

Pasquini, L., and Enqvist, J. P. (2019). Green Infrastructure in South African Cities. Report for Cities Support Programme. African Centre for Cities, University of Cape Town, South Africa. Available online at: https://www. africancentreforcities.net/green-infrastructure-in-south-african-cities/

Pauleit, S., Liu, L., Ahern, J., and Kazmierczak, A. (2011). "Multifunctional green infrastructure planning to promote ecological services in the city," in Handbook of Urban Ecology, ed. J. Niemelä (Oxford: Oxford University Press), 272-285.

Pauleit, S., Vasquéz, A., Maruthaveeran, S., Liu, L., and Cilliers, S. S. (2021). "Urban green infrastructure in the Global South," in Urban Ecology in the Global South, eds. C. M. Shackleton, S. S. Cilliers, E. Davoren, and M. J. du Toit (Cham: Springer), 107-143.

Pfab, M. F., Compaan, P. C., Whittington-Jones, C. A., Engelbrecht, I., Dumalisile, L., Mills, L., et al. (2017). The Gauteng conservation plan: Planning for biodiversity in a rapidly urbanising province. Bothalia 47:a2182. doi: $10.4102 /$ abc.v47i1.2182

Pillay, P. (2017). The Level of Awareness and Perceptions on Rooftop Gardens: Case of eThekwini Municipality City Centre. Master's thesis. University of KwaZulu-Natal, Durban.

Planchuelo, G., Kowarik, I., and von der Lippe, M. (2020). Endangered plants in novel urban ecosystems are filtered by strategy type and dispersal syndrome, not by spatial dependence on natural remnants. Front. Ecol. Evol. 8:18. doi: $10.3389 /$ fevo.2020.00018

Planning Partners (2005). Century City Urban Design Framework. Prepared for Century City Limited and the Property Owners Association in order to guide future development at Century City. Available online at: http://century-city.theartery.co.za/docs/udr_combined.pdf (accessed August 2, 2020).

Priority Zone Durban (2013). Rooftop Garden: Inner City Greening and Beautification. Available online at: http://priorityzone.weebly.com/rooftopgarden.html (accessed August 20, 2020).

Pro Landscaper Africa (2018). Third Anniversary Issue: Project Two the Keyes Art Mile. Available online at: www.prolandscaper.co.za (accessed August 21, 2020).

Roberts, D., Boon, R., Diederichs, N., Douwes, E., Govender, N., Mcinnes, A., et al. (2012). Exploring ecosystem-based adaptation in Durban, South Africa: "learning-by-doing" at the local government coal face. Environ. Urban. 24, 167-195. doi: 10.1177/0956247811431412

Rodenburg, C. A., and Nijkamp, P. (2004). Multifunctional land use in the city: a typological overview. Built Environ. 30, 274-288. doi: 10.2148/benv.30.4.274.57152

Rupprecht, C. D., and Byrne, J. A. (2014). Informal urban green-space: comparison of quantity and characteristics in Brisbane, Australia and Sapporo, Japan. PLoS One. 9:e99784. doi: 10.1371/journal.pone.0099784

Schäffler, A., Christopher, N., Bobbins, K., Otto, E., Nhlozi, M., De Wit, M., et al. (2013). State of Green Infrastructure in the Gauteng City-Region. Johannesburg:
University of Johannesburg, the University of the Witwatersrand, Johannesburg, and the Gauteng Provincial Government. Gauteng CityRegion Observatory (GCRO). Available online at: https://www.google. co.za/url sa $=$ tandrct $=$ jand $q=$ andesrc $=$ sandsource $=$ weband $d=3$ andved $=$ 2ahUKEwiyhLmrnKTpAhUzThUIHas9CLQQFjACegQIBhABandurl=https \%3A\%2F\%2F (accessed May 8, 2020).

Schäffler, A., and Swilling, M. (2013). Valuing green infrastructure in an urban environment under pressure-The Johannesburg case. Ecol. Econ. 86, 246-257. doi: 10.1016/j.ecolecon.2012.05.008

Selman, P. (2009). Planning for landscape multifunctionality. Sustainability 5, 45-52. doi: 10.1080/15487733.2009.11908035

Shackleton, C. M. (2021). "Provisioning services in Global South cities," in Urban Ecology in the Global South, eds. C. M. Shackleton, S. S. Cilliers, E. Davoren, and M. J. du Toit (Cham: Springer), 203-226.

Shackleton, C. M., Blair, A., de Lacy, P., Kaoma, H., Mugwagwa, N., Dalu, M. T., et al. (2018). How important is green infrastructure in small and medium sized towns? Lessons from South Africa. Landsc.Urban Plan. 180, 273-281. doi: 10.1016/j.landurbplan.2016.12.007

Shackleton, C. M., Cilliers, S. S., Du Toit, M. J., and Davoren, E. (2021). “The need for a Urban Ecology of the Global South," in Urban Ecology in the Global South, eds. C. M. Shackleton, S. S. Cilliers, E. Davoren, and M. J. du Toit (Cham: Springer), 1-26.

Sharmin, F. (2020). Towards the valuation of open spaces: a Hedonic based investigation for sustainable planning in the dense urban context of Dhaka. Ame. J. Environ. Resour. Econ. 5, 97-103.

Stafford-Smith, M., Griggs, D., Gaffney, O., Ullah, F., Reyers, B., Kanie, N., et al. (2017). Integration: the key to implementing the Sustainable Development Goals. Sustainability 12, 911-919. doi: 10.1007/s11625-0160383-3

Steenberg, R. (2013). "Landscaping project produces a sustainable rain garden," in Innovate Issue 08 2013, ed M. W. Pretorius (South Africa: University of Pretoria), 24-27.

Steenkamp, J., Cilliers, E. J., Cilliers, S. S., and Lategan, L. (2021). Food for thought: addressing urban food security risks through urban agriculture. Sustainability 13:1267. doi: 10.3390/su13031267

Stiles, R. (2009). Urban Spaces-Enhancing the Attractiveness and Quality of the Urban Environment. Project UrbSpace. Vienna University of Technology. Available online at: http://urbanspace.rec.org/files/Working\%20Paper\%203.1. 2_FINAL.pdf (accessed May 4, 2020).

Tan, P. Y. (2017). "Perspectives on greening of cities through an ecological lens," in Greening Cities: Forms and Functions, eds. P. Y. Tan, and C. Y. Jim (Singapore: Springer), 15-41.

Taylor, A. (2016). Institutional inertia in a changing climate: climate adaptation planning in Cape Town, South Africa. Int. J. Clim. Change Strat. Manag. 8, 194-211. doi: 10.1108/IJCCSM-03-2014-0033

TEEB (2010). The Economics of Ecosystems and Biodiversity: Mainstreaming the Economics of Nature. A Synthesis of the Approach, Conclusions and Recommendations of TEEB. Available online at: www.teebweb.org (accessed May 13, 2020).

The City of Cape Town (2010). City of Cape Town Nature Reserves: A Network of Amazing Biodiversity. Available online at: www.capetown.gov.za/environment (accessed August 20, 2020).

The City of Cape Town (2016). A History of Cape Town's District Parks. Available online at: www.capetown.gov.za/environment (accessed August 24, 2020).

The Scottish Government (2011). Green Infrastructure: Design and Placemaking. Scottish Government. Available online at: https:/www.gov.scot/binaries/ content/documents/govscot/publications/advice-and-guidance/2011/11/ green-infrastructure-design-placemaking/documents/0122541-pdf/0122541pdf/govscot:document/0122541.pdf (accessed May 7, 2020).

Titus, N., and Spencer, J. P. (2015). A new tourism practice-developing a model for slow tourism at heritage sites and protected areas: a case of Kirstenbosch National Botanical Gardens, South Africa. AJPHERD 21, 1232-1246. Available online at: https://www.news.uct.ac.za/article/-2004-1101-doing-it-differently-the-story-of-intaka-island

United Nations (2021). Sustainable Development Goals. Goal 11: Make Cities Inclusive, Safe, Resilient and Sustainable. Available online at: https:/www.un.org/sustainabledevelopment/cities/ (accessed May 8, 2021). 
University of Cape Town. (2004). Doing It Differently - The Story of Intaka Island. Available online at: https://www.news.uct.ac.za/article/-200411-01-doing-it-differently-the-story-of-intaka-island (accessed August 4, 2020).

Valencia, S. C., Simon, D., Croese, S., Nordqvist, J., Oloko, M., Sharma, T., et al. (2019). Adapting the Sustainable Development Goals and the New Urban Agenda to the city level: initial reflections from a comparative research project. Int. J. Urban Sustain. Dev. 11, 4-23. doi: 10.1080/19463138.2019. 1573172

Van Zyl, B., Lategan, L. G., Cilliers, E. J., and Cilliers, S. S. (in press). Closing the gap between urban planning and urban ecology: a South African perspective. Urban Plan 6. doi: 10.17645/up.v6i4.4456

Venter, Z. S., Shackleton, C. M., van Staden, F., Selomane, O., and Masterson, V. A. (2020). Green apartheid: urban green space remains unequally distributed across income and race geographies in South Africa. Landsc. Urban Plan. 203:103889. doi: 10.1016/j.landurbplan.2020. 103889

Ward, C. D., Parker, C. M., and Shackleton, C., M. (2010). The use and appreciation of botanical gardens as urban green spaces in South Africa. Urban For. Urban Gree. 9, 49-55. doi: 10.1016/j.ufug.2009. 11.001

Watson, V. (2016). Locating planning in the New Urban Agenda of the urban sustainable development goal. Plan. Theory 15, 435-448. doi: $10.1177 / 1473095216660786$

Wei, L. (2017). Multifunctionality of Urban Green Space-An Analytical Framework and the Case Study of Greenbelt in Frankfurt am Main, Germany. PhD thesis, Technical University of Berlin, Darmstadt.

Wilkerson, M. L., Mitchell, M. G., Shanahan, D., Wilson, K. A., Ives, C. D., Lovelock, C. E., et al. (2018). The role of socio-economic factors in planning and managing urban ecosystem services. Ecosyst. Serv. 31, 102-110. doi: 10.1016/j.ecoser.2018.02.017
Willis, C., and Morkel, A. (2008). National Botanical Gardens: South Africa's urban conservation refuges. BGjournal 5, 4-7. Available online at: https://www.jstor. org/stable/24810656

Wright, H. (2011). Understanding green infrastructure: the development of a contested concept in England. Local Environ. 16, 1003-1019. doi: 10.1080/13549839.2011.631993

Wynne-Jones, C. (2005). The Valuation of Intaka Island: A Comparison of the Contingent Valuation Method and Hedonic Pricing Analysis. Master's dissertation, University of Cape Town, Cape Town.

Živković, J., Lalović, K., Milojević, M., and Nikezić, A. (2019). Multifunctional public open spaces for sustainable cities: concept and application. FU Arch. Civ. Eng. 17, 205-219. doi: 10.2298/FUACE190327012Z

Conflict of Interest: The authors declare that the research was conducted in the absence of any commercial or financial relationships that could be construed as a potential conflict of interest.

Publisher's Note: All claims expressed in this article are solely those of the authors and do not necessarily represent those of their affiliated organizations, or those of the publisher, the editors and the reviewers. Any product that may be evaluated in this article, or claim that may be made by its manufacturer, is not guaranteed or endorsed by the publisher.

Copyright (C) 2021 Van Zyl, Lategan, Cilliers and Cilliers. This is an open-access article distributed under the terms of the Creative Commons Attribution License (CC $B Y)$. The use, distribution or reproduction in other forums is permitted, provided the original author(s) and the copyright owner(s) are credited and that the original publication in this journal is cited, in accordance with accepted academic practice. No use, distribution or reproduction is permitted which does not comply with these terms. 